\title{
Identification of Changes in Water Catchment Areas in Kulon progo District Using Geographic Information Systems
}

\author{
DOI: 10.18196/pt.2020.120.103-113
}

\author{
Lis Noer Aini*, Ratri Sekarsari, and Bambang Heri Isnawan \\ Department of Agrotechnology, Faculty of Agriculture, Universitas Muhammadiyah Yogyakarta, \\ Jl Brawijaya, Kasihan, Bantul, 55183, Yogyakarta, Indonesia \\ *Corresponding author, email: nenny@umy.ac.id
}

\begin{abstract}
Water is the basic needs of living things in this world. Infrastructure development that increased would cause the needs of water. Therefore, it has to be balanced with manage the good plan of water absorption region in an area. This research has been done in Kulon Progo districts that aimed at made maps and map the potential of water absorption region in Kulon Progo districts. The method used in this research was the tiered quantitative analysis survey with Geography Information System (SIG) software with the weighting parameter categorize model using overlap techniques in each parameter. The parameters were kind of rocks, rainfall, used land, and slope of the land. The data of the research was secondary data. Those were administration map, Topographycal map, land used map, rainfall data, Shuttle Radar Topography Mission (SRTM), and soil map. The result of this research showed that water absorption region in Kulon Progo with dominated suitability condition in unsuitable class as wide as 32.804 ha followed by class as wide as 17.124 ha, and the smallest was class condition quite appropriate as wide as 7.976 ha.
\end{abstract}

Keywords: ArcGIS, Weighting factor, Infiltration

\section{ABSTRAK}

Air adalah kebutuhan pokok makhluk hidup di bumi ini. Pembangunan infrakstruktur yang terus meningkat yang juga diimbangi dengan bertambahnya jumlah manusia berakibat pada meningkatnya kebutuhan air bersih. Oleh karena itu harus diimbangi dengan mengelolaan perencanaan tata kelola daerah resapan air yang baik di suatu daerah. Penelitian ini dilaksanakan di Kabupaten Kulon Progo pada bulan yang bertujuan untuk membuat peta dan memetakan potensi daerah resapan air yang berada di Kabupaten Kulon Progo. Metode yang digunakan dalam penelitian ini yaitu adalah survei analisis kuantitatif berjenjang menggunakan perangkat lunak Sistem Informasi Geografi (SIG) dengan model pengkelasan parameter pembobotan menggunakan teknis overlay pada masing-masing parameter yaitu jenis batuan, curah hujan, penggunaan lahan, dan kemiringan lahan. Jenis data yang digunakan yaitu data sekunder antara lain peta administrasi, peta Rupabumi Indonesia (RBI), peta penggunaan lahan, data curah hujan, Shuttle Radar Topography Mission (SRTM), dan peta tanah. Hasil penelitian menunjukkan bahwa daerah resapan air di Kabupaten Kulon Progo dengan kondisi kesesuaian paling mendominasi pada kelas tidak sesuai yaitu seluas 32.804 ha diikuti oleh kelas sesuai seluas 17.124 ha, dan yang paling kecil adalah pada kondisi kelas cukup sesuai yaitu seluas 7.976 ha.

Kata Kunci: ArcGIS, Pembobotan, Infiltrasi

\section{INTRODUCTION}

Current regional development prioritizes economic interests and the need for space to support economic interests, namely infrastructure for economic improvement. Environmental values are often disregarded and neglected, causing land conversion to become more prevalent. Spatial planning carried out prioritizes economic development, such as the development of tourist areas. Other areas considered less profitable that include the environmental sector are often neglected, such as water catchment areas that are still often forgotten (Wibowo, 2006). A water catchment area is an area that has a high capacity as a place for rainwater to absorb into the ground, which then, through natural processes, will become groundwater. Water catchment area has essential benefits in maintaining the sustainability of the function of water sources (Awanda et al., 2017)

Parameters of an area to be used as a water catchment area are soil texture, constituent rocks, rainfall, land slope, and land use types with certain characteristics (Perda Kota Manado, 2014; Permen PU, 2013). Groundwater generally comes from rainwater, which depends on local climatic conditions, including the amount and intensity of the rainfall (Zaidi et al., 2015). Many factors influence groundwater movement in an area, including topography, source rock, geological structure, land 
use, land slope, land shape, drainage patterns, and climate (Yeh et al., 2016; Prasetyo et al., 2016). Until now, there are no standard and definite criteria to determine water catchment areas. The standard criteria for water catchment areas should be set by the central government so that it can be a preference for local governments in zoning areas that have the potential to infiltrate water into the ground. Water catchment areas are needed because, in addition to functioning as an addition to groundwater reserves, they are also used to reduce the potential for flooding (Wibowo, 2006).

The process of water infiltration into the soil consists of two stages, which are infiltration and percolation stages. The infiltration stage is the movement of water from the earth's surface into the soil body, and the placement stage is the movement of water in the soil body (unsaturated zone) from the topsoil layer to the lower soil layer (water-saturated zone) (Sonaje, 2013). The infiltration and percolation processes play an important role in replenishing soil moisture and groundwater. Groundwater infiltration will determine the amount of base flow that is the minimum river discharge in the dry season (Wibowo, 2003).

Presidential Decree No. 32/1990 concerning Protected Area Management stipulates that water infiltration areas are classified as protected areas to protect the area underneath. It is reinforced by the Decree of the State Minister for the Environment No. 39 / MENLH / 8/1996 concerning Business or Activities that Require an AMDAL study, which states that all activities in protected areas, including those in water catchment areas, must be completed with an AMDAL study. It shows that the Decree of the State Minister for the Environment No. 39 / MENLH / 8/1996 classifies water catchment areas as protected areas because they have the same criteria. A protected area is an area or area whose physical condition and characteristics have a protection function for the preservation of natural resources such as water, flora, and fauna. Meanwhile, conservation areas are generally associated with the function of protecting water and soil systems. Therefore, conservation areas are part of the protected areas. The general criteria for protected areas are an altitude of $>1,500 \mathrm{~m}$ asl, a land slope of $<40 \%$, erosion-prone, rainfall of $>1,500$ $\mathrm{mm} /$ year, land use as forest.

The phenomenon of land-use change that occurred in Kulon Progo is the construction of the New Yogyakarta International Airport (NYIA), the expansion of mining areas, and the proliferation of housing developments. As a result, agricultural land changed from 45,324 ha in 2013 to 45,138 ha in 2017. Besides, the population growth from year to year also threatens the existence of clean water, at a time when infrastructure development is also increasingly prevalent. The construction of NYIA and the infrastructure will increase Regional Original Revenue (PAD), resulting in the construction of hotels, companies, and shopping centers that have sprung up after the airport. It appears because the existence of an airport will attract new investors who have an impact on regional development so that it can cause land changes that will impact the state of water catchment areas (Kustiningsih, 2017).

Infrastructure development that is rapidly increasing is likely to have the potential to damage water catchment areas, affecting the quantity and quality of clean water in the area. The decreasing quantity and quality of groundwater will lead to a negative impact on social, economic, and environment. Therefore, the increasing use of groundwater must be balanced with good management planning. Otherwise, it will gradually result in less groundwater, thereby generating a negative impact on all living things.

Based on the description above, it is necessary to identify changes in the potential for water catch- 
ment areas in Kulon Progo Regency due to the changes in infrastructure through water catchment area mapping as an effort to provide information on the water catchment areas that must be maintained.

\section{MATERIALS AND METHOD}

This research was conducted from January to May 2019 in Kulon Progo Regency. The method used in this research was a survey method. The data used were secondary data, including the data of land-use (from the Central Bureau of Statistics (BPS)), rainfall (from the Meteorology, Climatology and Geophysics Agency (BMKG)), land slope and rock types (from the Regional Development Planning Agency (BAPPEDA) of Kulon Progo Regency), and base maps of topographical maps of Indonesia, land cover maps, and satellite imagery of Kulon Progo area (from websites such as the United States Geological Survey (USGS), Google Earth, and the Geographic Information Agency (BIG)). The data (2012 and 2018) were used to see the changes in water catchment areas due to land conversion. The analysis used was tiered quantitative analysis using GIS software with overlay analysis, which was done by overlaying each parameter and producing weighted parameter criteria (Wibowo, 2006). The parameters included rock type, rainfall, land use, and land slope. The weighting criteria and the weighted parameters are presented in Table 1 and Tables 2-5, respectively.

Table 1. Parameter Weighting

\begin{tabular}{lcc}
\hline Criteria & Total score & Suitability \\
\hline Good & $>48$ & Suitable \\
Normal & $44-47$ & Suitable \\
Slightly critical & $40-43$ & Quite suitable \\
Moderately critical & $37-39$ & Quite suitable \\
Critical & $33-36$ & Not suitable \\
Extremely critical & $<32$ & Not suitable \\
\hline
\end{tabular}

Source: Wibowo, 2006
A weighting analysis was performed, which was the sum of the product values and weights of the four parameters, including constituent rocks, land-use, rainfall, and land slope using overlapping techniques (overlay) with the Geographic Information System application (GIS) in ArcGIS 10.3 software. The analysis resulted in the classification of water catchment areas in Kulon Progo Regency. The formula for the total value of the weighting analysis is as follows:

$$
\begin{aligned}
\text { Total value }= & ((\mathrm{Kb} \times \mathrm{Kp})+(\mathrm{Pb} \times \mathrm{Pp})+ \\
& (\mathrm{Sb} \times \mathrm{Sp})+(\mathrm{Lb} \times \mathrm{Lp}))
\end{aligned}
$$

Remarks:

$$
\begin{aligned}
& \mathrm{K}=\text { Rock type } \\
& \mathrm{P}=\text { Rain } \\
& \mathrm{S}=\text { Land-use } \\
& \mathrm{L}=\text { Land slope } \\
& \mathrm{b}=\text { Weight point } \\
& \mathrm{p}=\text { Score of parameter class }
\end{aligned}
$$

Table 2. Weight of rock type

\begin{tabular}{lccc}
\hline Rock type & Score & Weight & Category \\
\hline Alluvial sediments & 5 & 5 & Very high \\
$\begin{array}{l}\text { Young quaternary } \\
\text { sediments }\end{array}$ & 4 & 5 & High \\
$\begin{array}{l}\text { Old quaternary } \\
\text { sediments }\end{array}$ & 3 & 5 & Moderate \\
$\begin{array}{l}\text { Tertiary sediments } \\
\text { Intrusive rocks }\end{array}$ & 2 & 5 & Low \\
Body of water & 1 & 5 & Very low \\
\hline
\end{tabular}

Source: Wibowo, 2006

Table 3. Weight of rainfall

\begin{tabular}{lccc}
\hline $\begin{array}{l}\text { Spatial classification of } \\
\text { infiltration rain }\end{array}$ & Score & Weight & Category \\
\hline$>5500$ & 5 & 4 & Very high \\
$4500-5500$ & 4 & 4 & High \\
$3500-4500$ & 3 & 4 & Moderate \\
$2500-3500$ & 2 & 4 & Low \\
$<2500$ & 1 & 4 & Very low \\
\hline
\end{tabular}

Source: Wibowo, 2006 
Table 4. Weight of land-use

\begin{tabular}{lccc}
\hline Classification & Score & Weight & Category \\
\hline Forest & 5 & 3 & Very high \\
Plantation/Estate & 4 & 3 & High \\
Meadow & 3 & 3 & Moderate \\
Moor & 2 & 3 & Low \\
Rice field & 1 & 3 & Very low \\
Residential area & 1 & 3 & Very low \\
Open field & 1 & 3 & Very low \\
Body of water & 0 & 3 & - \\
\hline
\end{tabular}

Source: Wibowo, 2006

Table 5. Weight of land slope

\begin{tabular}{lccc}
\hline Slope & Score & Weight & Category \\
\hline$<8 \%$ & 5 & 2 & Very high \\
$8-15 \%$ & 4 & 2 & High \\
$15-25 \%$ & 3 & 2 & Moderate \\
$25-40 \%$ & 2 & 2 & Low \\
$>40 \%$ & 1 & 2 & Very low \\
\hline
\end{tabular}

Source: Wibowo, 2006

\section{RESULTS AND DISCUSSION}

A water catchment area is an area that must be available as a place for water to infiltrate as a water source. According to the Regulation of the Minister of Public Works No. 02/2013 concerning Guidelines for Preparation of Water Resources Management Plans, water catchment areas are areas that have particular characteristic parameters (rock types, rainfall, soil texture, land slope, and land-use) of a water catchment. One of the models for classifying the water catchment area parameters can be differentiated using a scoring method based on four parameters, namely rock type, rainfall, landuse, and land slope, with different weight values ranging from good to extremely critical (Table 1). The highest weight for an area to be used as a water catchment area is the rock type, followed by infiltration rainfall, land-use type, and the last is the land slope.

Based on the geological map and the results of the spatial analysis of Kulon Progo Regency, there were four types of rock, including alluvial sediments, tertiary sediments, young quaternary

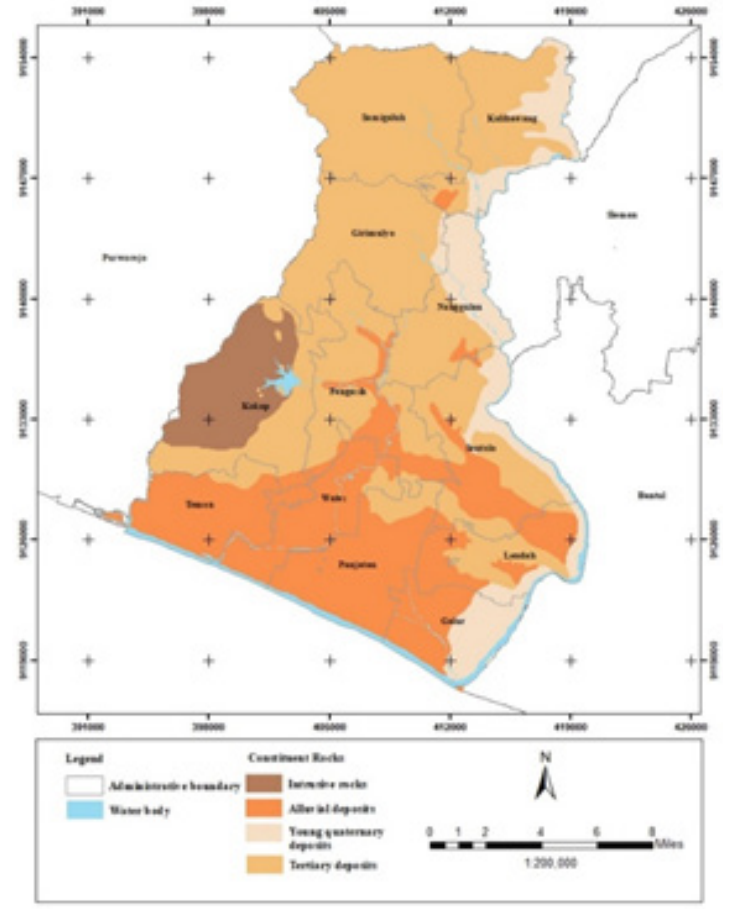

Figure 1. Map of geology in Kulon Progo Regency

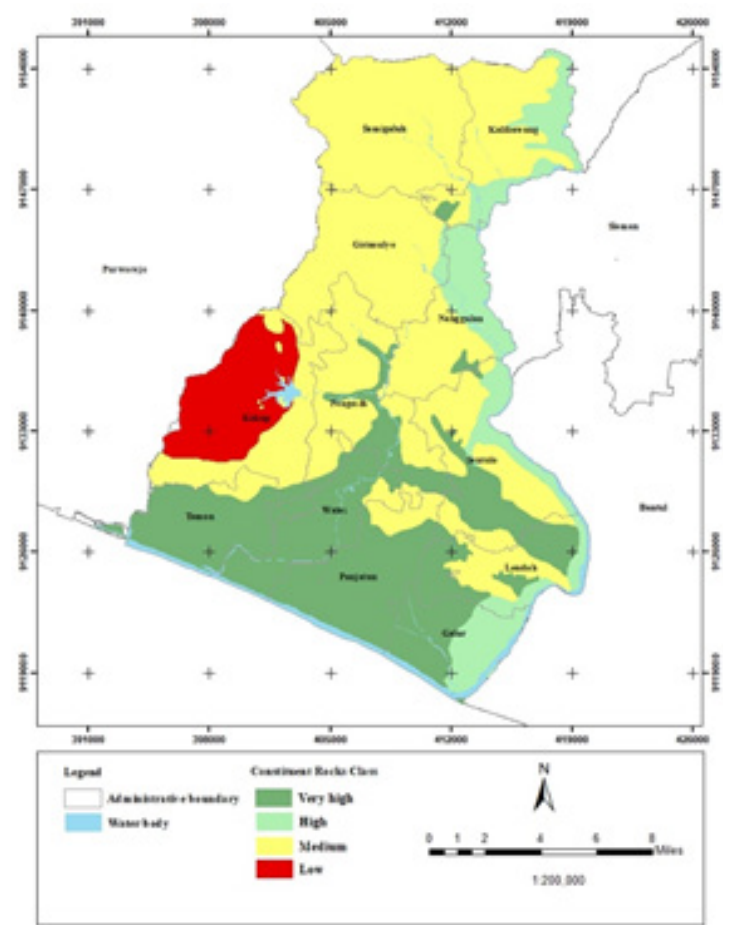

Figure 2. Map of constituent rock classes in Kulon Progo Regency

sediments, and intrusive rocks (Figure 1). The map of the constituent rock types is presented in Figure 2. The analysis results of the rock types show that areas in Kulon Progo mostly cannot be used as a water catchment area, indicated by the constituent 
Table 6. Category of rock type based on the weighting results

\begin{tabular}{lcccccc}
\hline Rock type & Score & Weight & Total score & Area (ha) & Percentage (\%) & Category \\
\hline Alluvial sediments & 5 & 5 & 25 & 16,889 & 29.2 & Very high \\
Young quaternary sediments & 4 & 5 & 20 & 6,753 & 11.7 & High \\
Old quaternary sediments & 3 & 5 & 15 & 0 & 0.0 & Moderate \\
Tertiary sediments & 2 & 5 & 10 & 29,657 & 51.2 & Low \\
Intrusive rocks & 1 & 5 & 5 & 3,969 & 6.8 & Very low \\
X3 & 0 & 5 & 0 & 634 & 1.1 & - \\
\hline Area of research location (Kulon Progo Regency) & & & 57,904 & 100 & \\
\hline
\end{tabular}

rocks in the form of tertiary deposits that have a low water absorption capacity (Table 6). These tertiary deposits dominate Kulon Progo area, accounting for $51.2 \%$ of the total area. Tertiary sediment, when used as a water catchment area, has a score of 2 , indicating a low ability to pass water. An area suitable for a water catchment area is alluvial sediment that has an area of $29.2 \%$ with a total score of 25 , classified in the very high category (Table 6). Alluvial can easily pass water so that the infiltration process occurs faster, thereby reducing the possibility of surface runoff so that areas with alluvial deposits have a very high potential to pass water. Young quaternary sediments cover $11.7 \%$ of the total area. Young quaternary sediments can pass water well, categorized in the high category. The scoring results on rock type parameters, the area that can be used as a water catchment area is $40.8 \%$ of the total area. The map of constituent rock classes in Kulon Progo Regency is presented in Figure 2.

The analysis of rainfall was performed using rainfall data taken from the Meteorology, Climatology, and Geophysics Agency (BMKG) for the period of 2012 and 2018. The data were collected from six rain stations located in the Kulon Progo area, which were BPP Kalibawang, BPP Lendah, BPP Singkung / Nanggulan, BPP Kokap, BPP Sentolo, and BPP Temon. The analysis carried out was based on the amount of rain intensity in the area. The greater the rain intensity, the more rainwater can pass into the soil. Rainfall data and rainy days were analyzed using the infiltration rain factor calculated by the following formula:

$\mathrm{RD}=$ 0,01.P.Hh

Remarks:

$\mathrm{RD}=$ infiltration rain factor

$\mathrm{P}=$ annual rainfall

$\mathrm{Hh}$ = number of annual rainy days

(Source: Wibowo, 2006)

The results of weighting the rainfall parameters in 2012 and 2018 are presented in Table 7. Based on the weighting results, the amount of rainfall in 2012 was categorized in low (10\%) and very low (90\%) category. In 2018, the infiltration rainfall in Kulon Progo Regency was moderate (32\%) and very low (68\%) (Table 7). It is closely related to the amount of water received by the earth, which eventually enters the ground. However, the infiltration that occurs depends on the type of rock, soil type, and vegetation that covers the area. Based on the data obtained, the rainfall in 2012 was lower than in 2018. The change in the rainfall is highly Table 7. Category of infiltration rain based on the results of the weighting

\begin{tabular}{lcccc}
\hline \multirow{2}{*}{ Classification } & \multirow{2}{*}{ Total Score } & \multicolumn{2}{c}{ Land Area (ha) } & \multirow{2}{*}{ Category } \\
\cline { 2 - 4 } & & 2012 & $\mathbf{2 0 1 8}$ & \\
\hline$>5500$ & 20 & 0 & 0 & Very high \\
$4500-5500$ & 16 & 0 & 0 & High \\
$3500-4500$ & 12 & 0 & 18,512 & Moderate \\
$2500-3500$ & 8 & 5,726 & 0 & Low \\
$<2500$ & 4 & 52,178 & 39,392 & Very low \\
\hline Area of the location & & 57,904 & 57,904 & \\
\hline
\end{tabular}




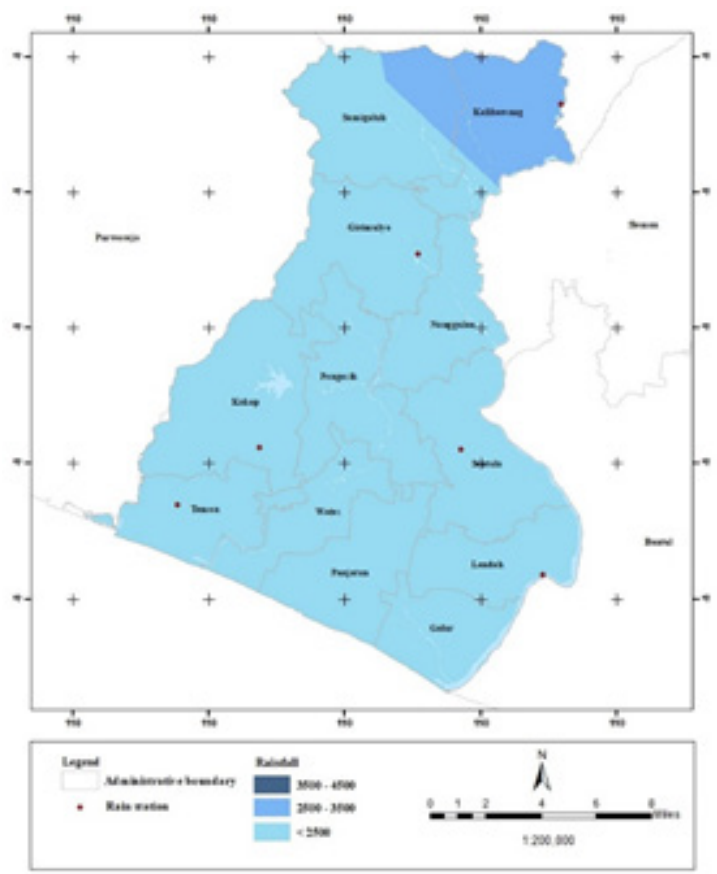

Figure 3. Map of rainfall in 2012 in Kulon Progo Regency

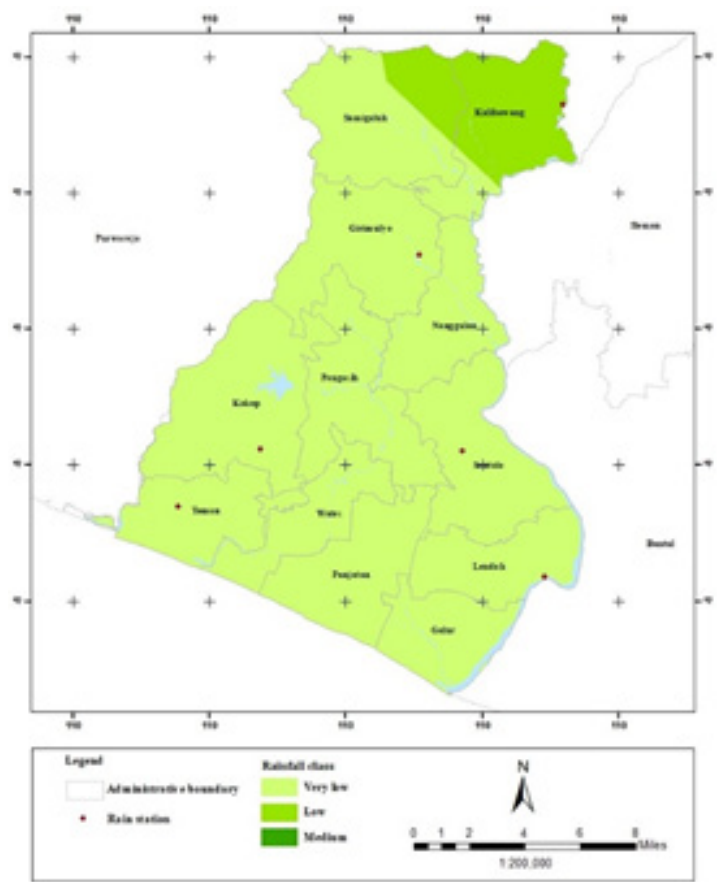

Figure 5. Map of rainfall classes in 2012 in Kulon Progo Regency

dependent on the climatic conditions. The maps of infiltration rainfall and rainfall class in Kulonprogo Regency are presented in Figures 3-4 and 5-6, respectively.

Land-use type is the second parameter that influences water catchment areas. Based on the

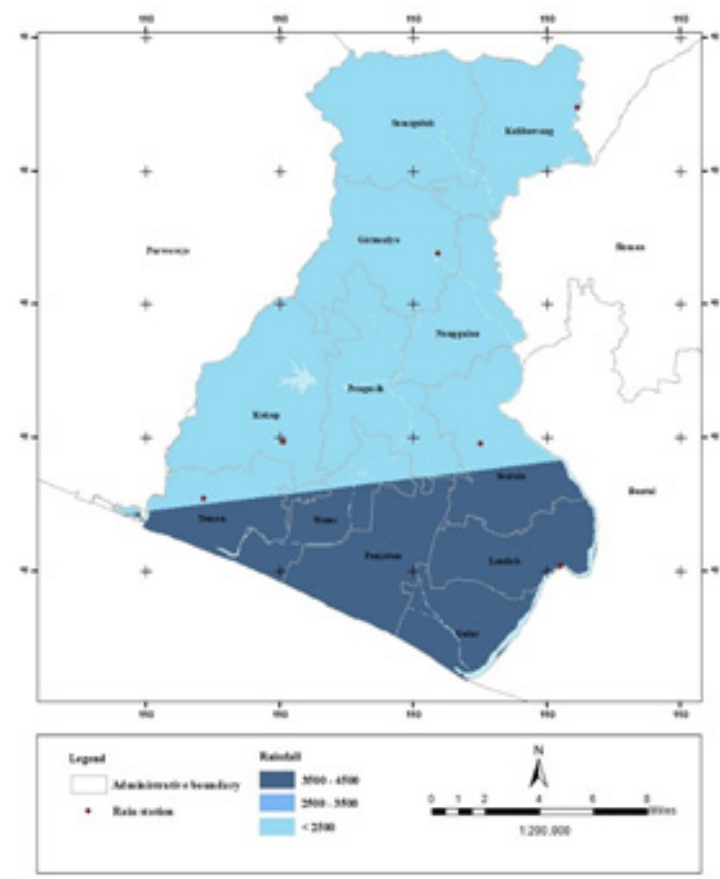

Figure 4. Map of rainfall in 2018 in Kulon Progo Regency

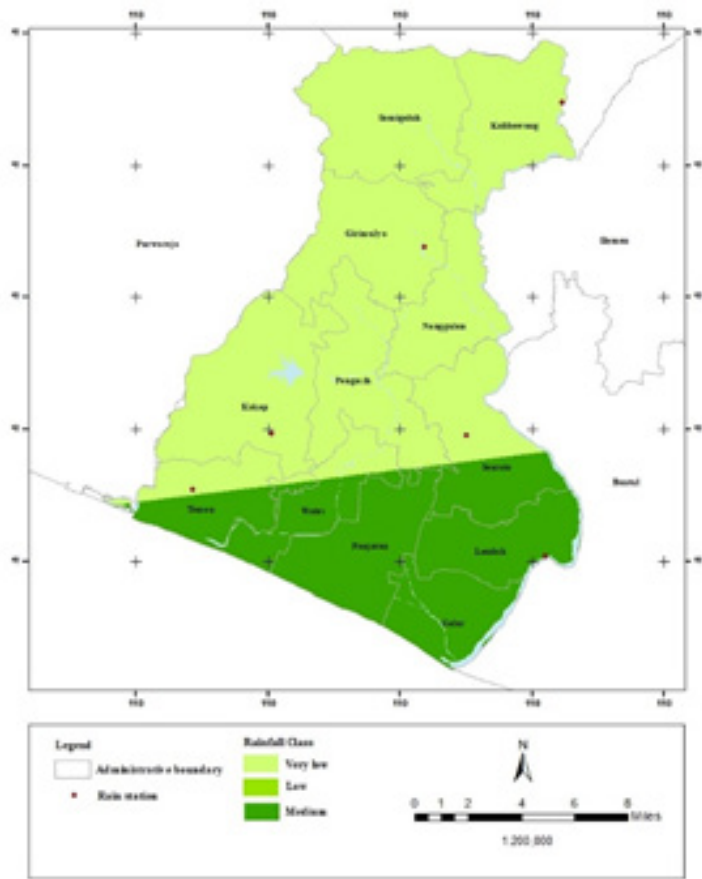

Figure 6. Map of rainfall classes in 2018 in Kulon Progo Regency

weighting of land-use, land that has a higher vegetation cover is better to be used as a water catchment area (Table 4). The results of the analysis of satellite imagery showed that in 2012, land-use in Kulon Progo Regency was still dominated by plantations (33\%). The total land used for agriculture and open 
land was $69.7 \%$, while the land used for residential area was $28.34 \%$. In 2018, the land-use in Kulonprogo Regency changed (Table 8). The land-use for agricultural land and open land decreased to $64.21 \%$, while the use of the area for residential area increased to $33.83 \%$.

Table 8. Land-use types in Kulon Progo Regency in 2012 and 2018

\begin{tabular}{lcc}
\hline Land-use & $\mathbf{2 0 1 2}$ & $\mathbf{2 0 1 8}$ \\
\hline Forest & 751 & 531 \\
Estate/plantation & 19.093 & 18,191 \\
Meadow & 725 & 549 \\
Moor & 9,707 & 6,320 \\
Rice field & 8,924 & 10,567 \\
Residential area & 16,410 & 19,589 \\
Open field & 1,159 & 1,021 \\
Body of water & 1,135 & 1,135 \\
\hline Total & 57,904 & 57,904 \\
\hline
\end{tabular}

The results of weighting the potential use of land as water catchment areas are presented in Table 9. Based on the land-use types, the land-use type with the highest category as a water catchment area is forest. In 2012, the number of forests in Kulonprogo Regency was remarkably low compared to the area $(1.3 \%)$. The land that has the highest potential for a water catchment area is plantation (33\%/high category). Meanwhile, the lowest potential with a large enough land use area $(28.34 \%)$ is in the residential area. In 2018, there was a change in land-use so that the potential for water catchment areas in Kulonprogo Regency changed as well. The area that is not potential for a water catchment area is getting larger, used for the residential area (33.83\%). Forests and plantations have the highest potential for water catchment areas even though their area changed to $31.42 \%$. Changes in land cover or vegetation cover will affect the changes in soil properties. It is because each type of vegetation has a different root system (Winanti in Utaya, 2008). The ability of the soil to absorb water can be seen from the types of vegetation on the soil surface. Each vegetation has different capabilities and functions in terms of the effectiveness of the
Table 9. Category of the land-use based on the weighting results

\begin{tabular}{|c|c|c|c|c|}
\hline \multirow{2}{*}{ Classification } & \multirow{2}{*}{ Total Score } & \multicolumn{2}{|c|}{ Land Area (ha) } & \multirow{2}{*}{ Category } \\
\hline & & 2012 & 2018 & \\
\hline Forest & 15 & 751 & 531 & Very high \\
\hline Estate/plantation & 12 & 19,093 & 18,191 & High \\
\hline Meadow & 9 & 725 & 549 & Moderate \\
\hline Moor & 6 & 9,707 & 6,320 & Low \\
\hline Rice field & 3 & 8,924 & 10,567 & Very low \\
\hline Residential area & 3 & 16,410 & 19,589 & Very low \\
\hline Open field & 3 & 1,159 & 1,021 & Very low \\
\hline Body of water & 0 & 1,135 & 1,135 & - \\
\hline Area of the location & & 57,904 & 57,904 & \\
\hline
\end{tabular}

soil in absorbing rainwater, maintaining or increasing the infiltration rate, and holding water or water resistance capacity (Setyowati, 2007). Soil physical properties in dense vegetation types tend to be better at absorbing water compared to the land that has sparse vegetation. Vegetation type will affect the type, composition, and density of vegetation due to its effect on the content of organic matter, the amount and thickness of litter, and soil biota that supports and determines the size and extent of the infiltration process (Lee, 1990; Setyowati, 2007). The difference in infiltration capacity is scientifically correct because the effect of vegetation on infiltration depends on different root systems (Winanti, 1996). The decrease in forest area can be due to a change in land functions, as well as several natural and non-natural factors. According to Purwantara (2015), the natural factors decreasing forest area are natural disasters such as forest fires, volcanic eruptions, storms, and flash floods. Kulon Progo Regency itself is part of the natural disaster-prone route because of the position of $\mathrm{Ku}$ lon Progo Regency, which is partly a plateau with a land slope of more than 25\%, namely the Districts of Samigaluh, Kalibawang, Girimulyo, and Kokap, making the area prone to landslides. Meanwhile, the non-natural factors decreasing the land area include illegal logging and shifting cultivation, as well as the increase in the tourism area in Kulon Progo. The results of land-use mapping in Kulon- 


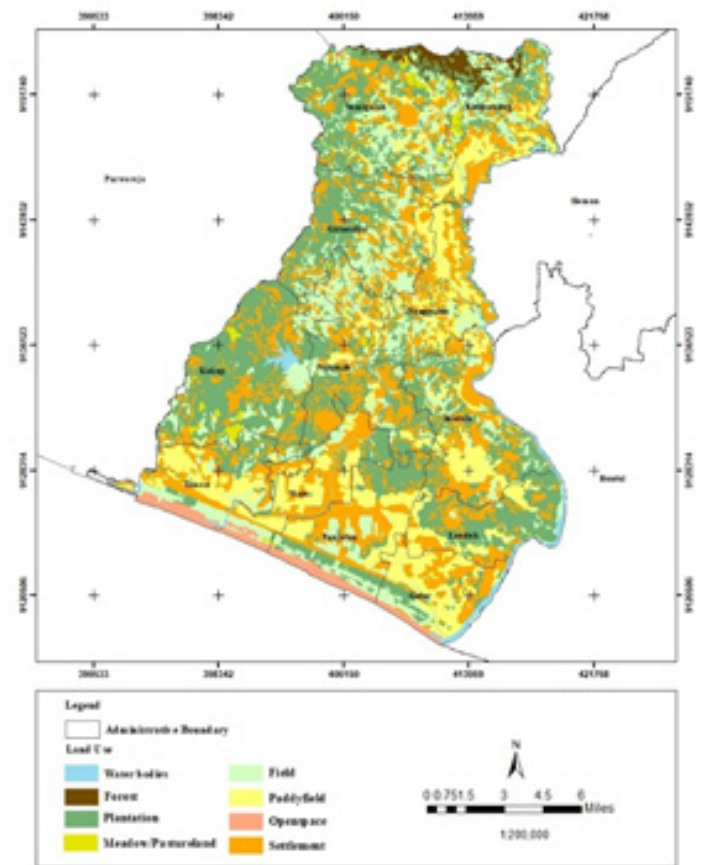

Figure 7. Map of the land-use in 2012 in Kulon Progo Regency

progo Regency are presented in Figures 7 and 8, and the weighted mapping results of land-use are presented in Figures 9 and 10.

Land slope is a determining factor for the third water catchment area with a weight of 2 . The slope classes are divided into five classes, namely $<8 \%$, $8-15 \%, 15-25 \%, 25-40 \%$, and $>40 \%$. Based on the results of the spatial analysis of land slopes in Kulon Progo Regency, it is dominated by land slope class $<8 \%$ with an area of 31,406 ha $(54.2 \%)$, followed by land slope class $15-25 \%$ with an area of 10,744 ha $(18.6 \%)$ of the total area (Table 10$)$.

Land slope affects the water catchment area because the greater the land slope, the greater the speed of water flowing on the surface if there are no obstacles. It is because there is a gravitational force that causes water to flow vertically into the soil through the soil profile more quickly. The slope gradient also affects erosion via runoff events. Thus, the steeper the slope, the greater the rate and amount of surface runoff, causing tremendous erosion (Ernawati et al., 2018; Arsyad, 2000). The map of land slope and land slope classes in Kulon Progo Regency are presented in Figures 11and 12, respectively.

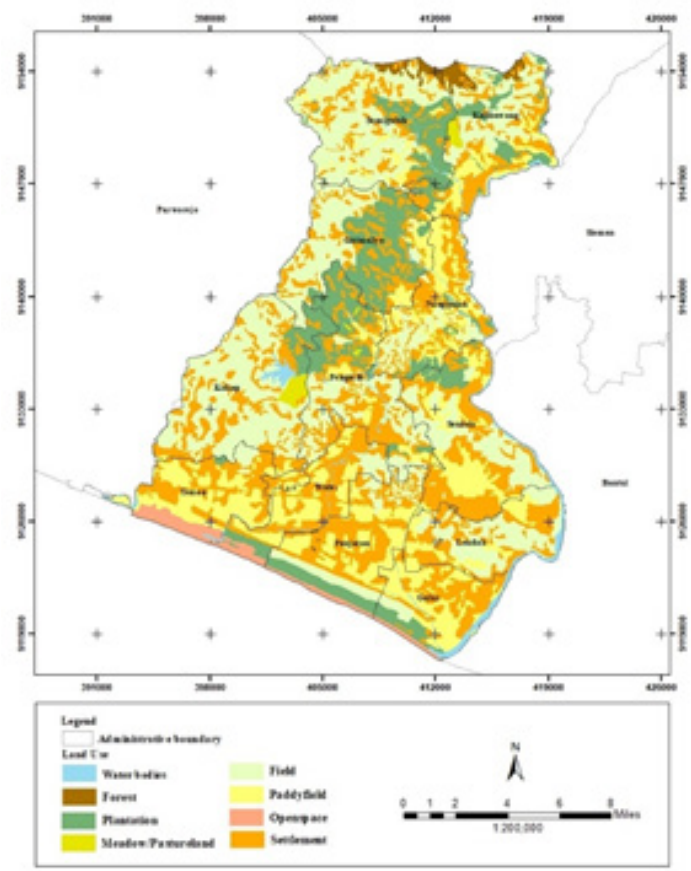

Figure 8. Map of the land-use in 2018 in Kulon Progo Regency

Land slope and erosion processes are related to each other concerning the length and steepness of a slope. Land with a steep slope between 30-45\% will have a more significant effect on gravity than land with a slightly steep slope, which is between $15-30 \%$. The greater gravity is in line with the inclination of the soil surface from the horizontal plane. This gravity is an absolute requirement for the process of detachment, transportation, and sedimentation (Wiradisastra, 1999). Water infiltration and various types of land slopes as a negative correlation, meaning that water infiltration will increase with the smaller land slope. On the contrary, the infiltration will decrease if the land slope is higher (Arfan and Pratama, 2014).

According to the calculation of the criteria for water catchment areas, there are six criteria for water catchment areas in Kulon Progo Regency, Table 10. Category of land slope based on the weighting results

\begin{tabular}{lcc}
\hline Slope & Area (ha) & Category \\
\hline$<8 \%$ & 31,406 & Very high \\
$8-15 \%$ & 2,998 & High \\
$15-25 \%$ & 10,744 & Moderate \\
$25-40 \%$ & 7,460 & Low \\
$>40 \%$ & 5,293 & Very low \\
\hline Location area & 57,904 & \\
\hline
\end{tabular}




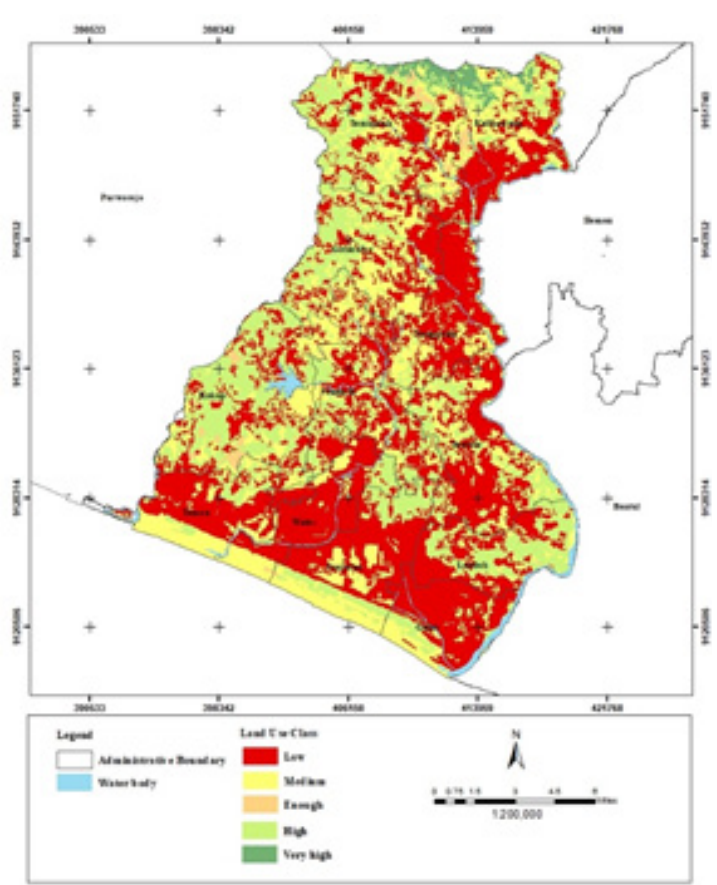

Figure 9. Map of the land-use classes in 2012 in Kulon Progo Regency

namely good, normal, slightly critical, moderately critical, critical, and extremely critical (Table 11). Most areas of Kulon Progo Regency have criteria for water catchment areas ranging from critical to extremely critical, covering $70.43 \%$ of the total area. Meanwhile, the area considered normal and good is $29.57 \%$ of the total area. Based on the suitability of water catchment areas (Table 12), most areas of Kulon Progo Regency are not suitable for water catchment areas.

Table 11. Criteria for water catchment area

\begin{tabular}{lcc}
\hline Criteria & Total Score & Area (ha) \\
\hline Good & $>48$ & 12,513 \\
Normal & $44-47$ & 4,611 \\
Slightly critical & $40-43$ & 4,571 \\
Moderately critical & $37-39$ & 3,405 \\
Critical & $33-36$ & 5,322 \\
Extremely critical & $<32$ & 27,482 \\
\hline Total & & 57,904 \\
\hline
\end{tabular}

Table 12. Suitability of water catchment area

\begin{tabular}{lccc}
\hline Suitability & Score & Area (ha) & Percentage (\%) \\
\hline Suitable & $44->48$ & 17,124 & 32 \\
Quite suitable & $37-43$ & 7,976 & 13 \\
Not suitable & $36-<32$ & 32,804 & 55 \\
\hline Total & & 57,904 & 100
\end{tabular}

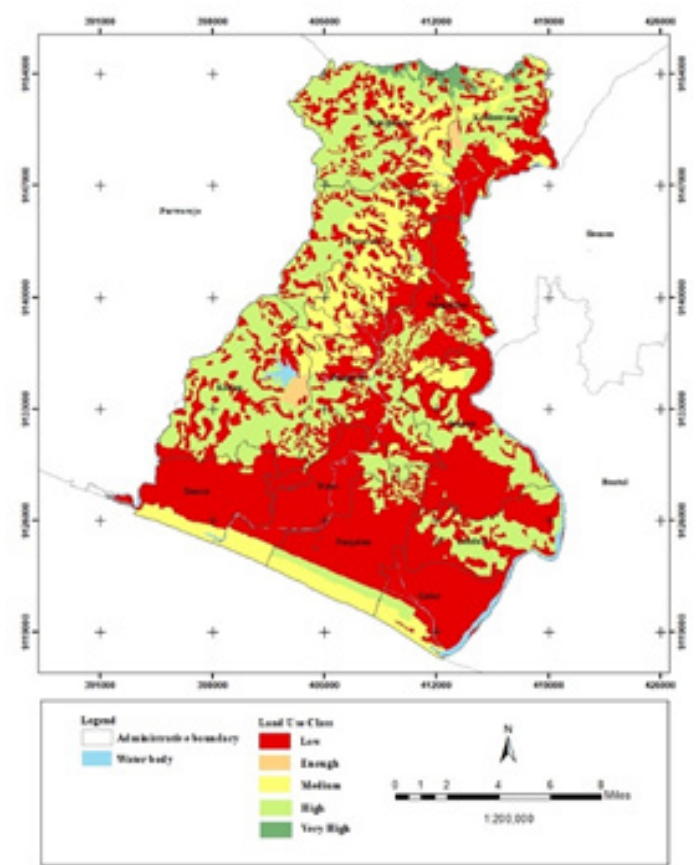

Figure 10. Map of the land-use classes in 2018 in Kulon Progo Regency

Based on the results of the analysis of the four parameters, namely rock type, rainfall, land-use, and land slope, the land used must be following the requirements of the water catchment area made by the government, namely a protected area with the conditions of land slope height $\langle 40 \%$, rainfall $>$ $1,500 \mathrm{~mm} /$ year, and land-use as a rain catchment area. The parameter that has the most significant effect on the water catchment area is the rock type. Rock type significantly affects water resources in terms of water sources, water resources, and water availability. Areas with alluvial rock types tend to be better at absorbing water due to the age of these rocks that are considered the youngest than other rock types. Besides, the type of coarse soil texture and the high organic matter content of the alluvial sediments causes the infiltration process to run optimally. Mother rock can affect soil type due to weathering effects. The older the rock, the greater the clay component. Clay can bind water well, but it is difficult to release it so that the quantity of water infiltration is small.

Infiltration rainfall is also related to water catchment areas. Rainwater is the main source 


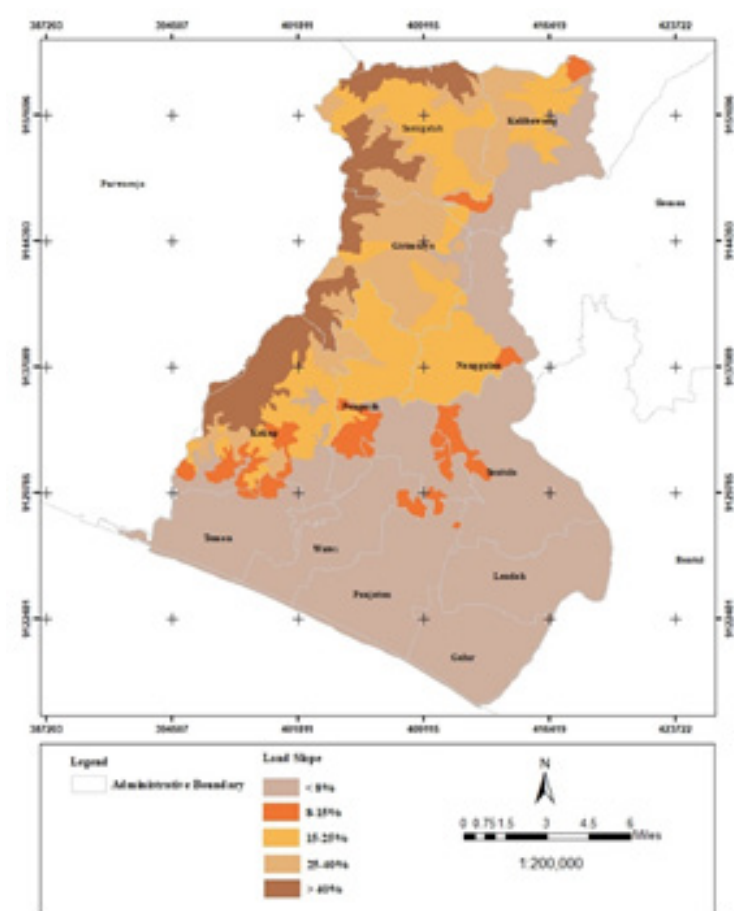

Figure 11. Map of land slope in Kulon Progo Regency

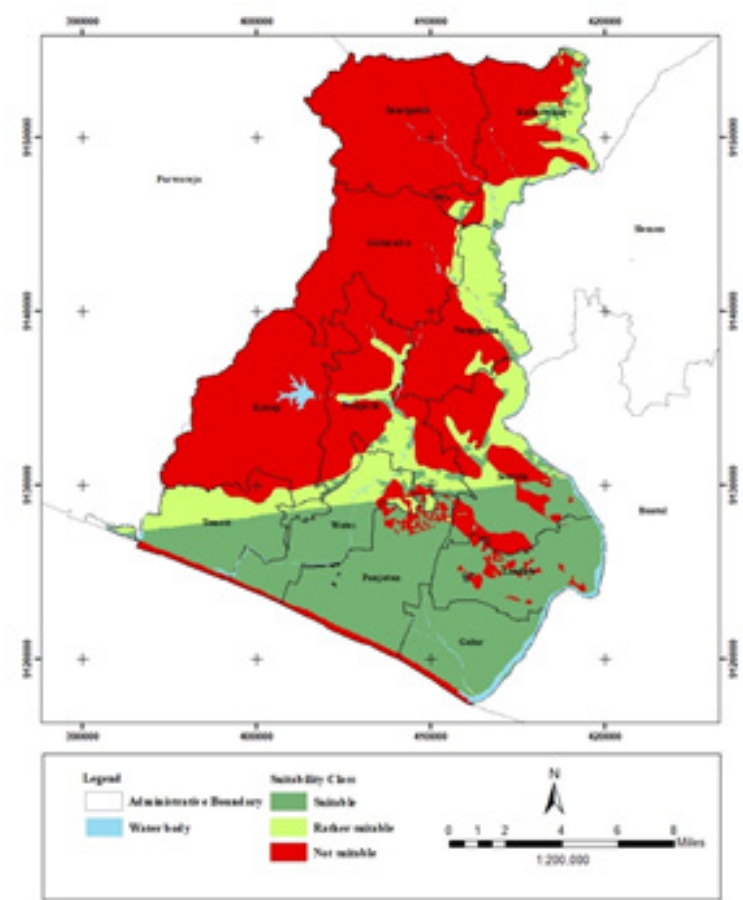

Figure 13. Map of water catchment area criteria in Kulon Progo Regency

of groundwater. The areas that have low rainfall, below $<1,500 \mathrm{~mm}$ or with an infiltration rainfall value of less than $<3,500 \mathrm{~mm} /$ year, cannot be used as water catchment areas.

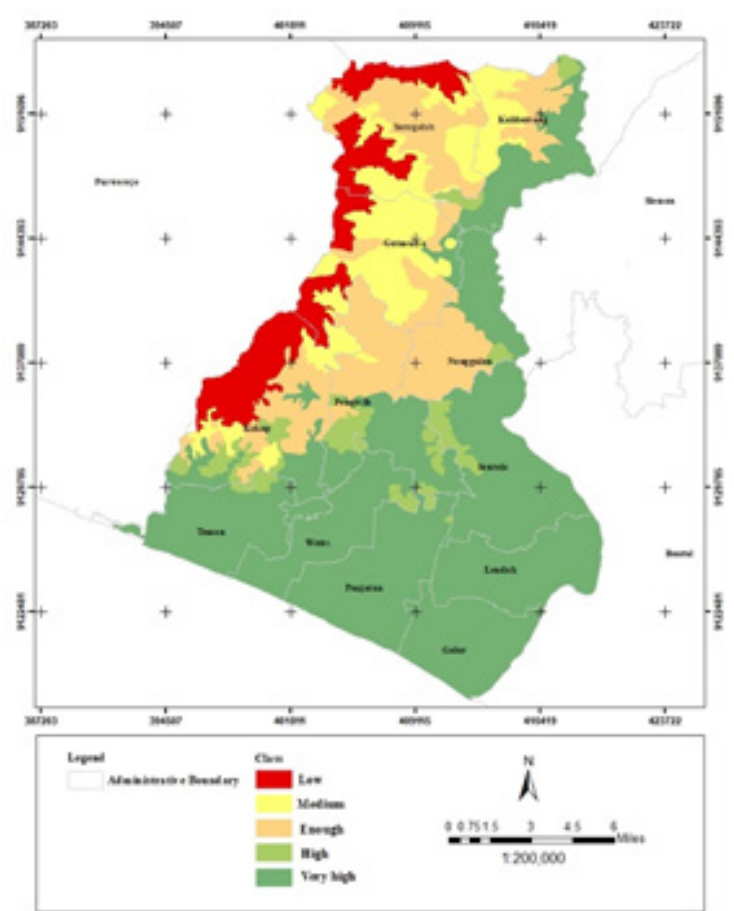

Figure 12. Map of land slope classes in Kulon Progo Regency

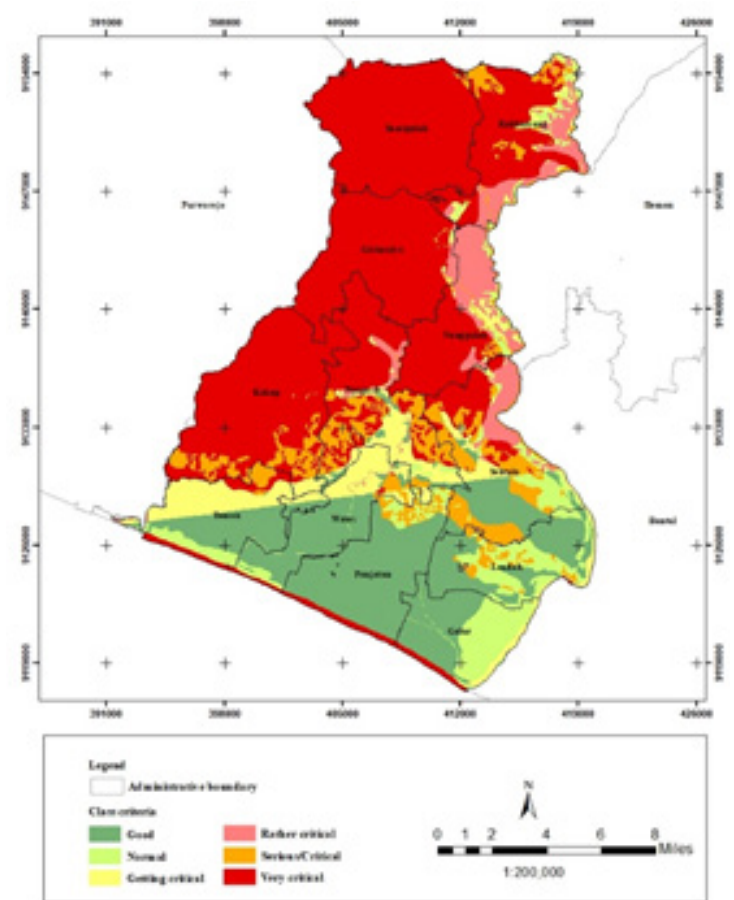

Figure 14. Map of the suitability classes of water catchment area in Kulon Progo Regency

Land-use type or vegetation type in an area is very influential in the infiltration process. The better the land cover, the better the water infiltration. According to Winanti in Utaya (2008), 
changes in land cover or vegetation cover will affect changes in soil properties. This is because each type of vegetation has a root system that is different from one another. The ability of the soil to absorb water is shown by the types of vegetation on the soil surface. Each vegetation type has different capabilities and functions in terms of the effectiveness of the soil in absorbing rainwater, maintaining or increasing the infiltration rate, and holding water (water resistance capacity).

The higher the degree of a land slope, the smaller the amount of water that absorbs due to the gravitational force that causes water to flow vertically into the soil through the soil profile more quickly. The slope gradient will also affect erosion through the runoff event. The steeper the slope, the greater the rate and the amount of surface runoff, which causes tremendous erosion (Arsyad, 2000). Thus, the four parameters are related to one another. If there is one parameter that is not suitable, the area can still be used as a catchment area with prior conservation (Figures 13 and 14).

\section{CONCLUSION}

The map of the water catchment area of Kulon Progo Regency is dominated by the unsuitable class, covering an area of 32,804 ha (55\%), scattered in Samigaluh, Kalibawang, Girimulyo, Nanggulan, Pengasih, and Kokap. The slightly suitable class is 17,124 ha $(32 \%)$, spread across the Districts of Kokap, Pengasih, Sentolo, Nanggulan, Lendah, Panjatan, and Kalibawang. Meanwhile, the class of moderately suitable covers an area of 7,976 ha (13\%), spread across Temon, Wates, Panjatan, Sentolo, Lendah, and Galur.

\section{REFERENCES}

Arfan, H. dan Pratama, A. (2014). Model Eksperimen Pengaruh Kepadatan, Intensitas Curah Hujan dan Kemiringan Terhadap Resapan Pada tanah Organik. Prosiding Hasil Penelitian Fakultas Teknik UNHAS. Hal 1-8.
Arsyad, S. (2000). Konservasi Tanah dan Air. Institut Pertanian Bogor Press. Bogor.

Awanda, D., A. Nurul, Z. Musfiroh, D. Dwi. (2017). Spatial Analysis for Potential Water Catchment Areas using GIS: Weighted Overlay Technique. The 5th Geoinformation Science Symposium 2017 (GSS 2017). IOP Conf. Series: Earth and Environmental Science 98: 012054

Ernawati, Sunaryo, Dedy Kurnia, Mabrur, Adkha Yulianandha. (2018). Pemanfaatan Sistem Informasi Geografis Untuk Analisis Potensi Daerah Resapan Air di Kabupaten Pati Jawa Tengah. Skripsi. Jurusan Teknik Geodesi, Fakultas Teknik Sipil dan Perencanaan, Institut Teknologi Nasional Malang.

Kustiningsih Wahyu. (2017). Kelompok Rentan dalam Pembangunan Kawasan Kota Bandara di Kulon Progo: Studi Kasus New Yogyakarta International Aiport (NYIA). Jurnal Pemikiran Sosiologi 4 (1). 91-105. https://doi.org/10.22146/jps.v4i1.23632.

Lee, R. (1990). Hidrologi Hutan. Yogyakarta: GamaPress.

Prasetyo, Y., S.A. Gunawan, and Z.U. Maksum. (2016). Determination of the water catchment area in Semarang City using a combination of object based image analysis (OBIA) classification, InSAR and Geographic Information System (GIS) methods based on a high-resolution SPOT 6 image and radar imagery. 2nd International Conference of Indonesian Society for Remote Sensing (ICOIRS) 2016. IOP Conf. Seri: Earth and Environ. Sci. 47012027.

Purwantara Suhadi. (2015). Dampak Pengembangan Permukiman Terhadap Air Tanah di Wilayah Yogyakarta dan Sekitarnya. Geoedukasi 4 (1): 31-40.

Setyowati Dewi Liesnoor. (2007). Sifat Fisik Tanah dan Kemampuan Tanah Meresapkan Air Pada Lahan Hutan, Sawah, dan Permukiman. Jurnal Geografi FIS UNNES 4 (2).

Sonaje, N.P. (2013). Modeling of Infiltration Process - a Review. Engineering vol. 3 issue 9: 226-230.

Utaya, (2008). Pengaruh Perubahan Penggunaan Lahan Terhadap Sifat Biofisik Tanah dan Kapasitas Infiltrasi di Kota Malang. Forum Geografi, Vol. 22, No. 2, Desember 2008: 99-112.

Wibowo, M. (2003). Teknologi Konservasi untuk Penanganan Kawasan Resapan Air dalam Suatu Daerah Aliran Sungai. J.Tek. Ling. P3TL-BPPT. 4(1): 8-13.

Wibowo, M. (2006). Model Penentuan Kawasan Resapan Air untuk Perencanaan Tata Ruang Berwawasan Lingkungan. Jurnal Hidrosfir 1 (1): 1-7.

Winanti, T. (1996). Pekarangan Sebagai Media Peresapan Air Hujan Dalam Upaya Pengelolaan Sumberdaya Air, Makalah disajikan dalam Konferensi Nasional Pusat Studi Lingkungan BKPSL, Tanggal 22-24 Oktober 1996 di Universitas Udayana, Denpasar Bali.

Wiradisastra. (1999). Geomorfologi dan Analisis Lanskap. Bogor, Laboratorium Penginderaan Jauh dan Kartografi Jurusan IImu Tanah Fakultas Pertanian.Institut Pertanian Bogor.

Yeh, H.F, Y.S. H.I. Lin, C.H. Lee. (2016). Mapping groundwater recharge potential zone using a GIS approach in Hualian River, Taiwan. Sustainable Environment Research 26: 33-43.

Zaidi, F.K., Y. Nazzal, I. Ahmed, M. Naeem, M.H. Jafri. (2015). Identification of potential artificial groundwater recharge zone in Noethwestern Saudi Arabia using GIS and Boolean logic. Journal of African Earth Science 111: 156-169. 